No operative interference for the removol of the growth could, of course, have heen of henefit, nor would the widespreod symptoms point to $n$ cortical lesion, unless to one of such extensive nrea as to have rendered its removnl extremely hozardous, if not impossihle. Bearing in mind the known dnnger of the use of anzesthetics in cases of hraintumor, yet apprecioting the importance of correcting an existent peripheral source of irritation, ether was given, hut in very small quantity. The good recovery from the effects of hoth the anesthesia nnd operation, nnd the intervnl hetreen these and the fotal ending, would indicate that the operative procedures could not have caused death except, possibly indirectly, hy incrensing in some way the vascularity ond, therefore, size of the growth.

\title{
INJURY OF CERVICAL SPINE, WITH LUXATION; REDUCTION; CORE.
}

\section{Bt ALexander W. Achesor, M.D.; or orxseos, trat}

F. J. W., aged fifty-five Jears, a railroad conductor in the employ of the Missouri, Kaosas \& Texus Railway, on the 10th of July, 1889, nt the town of St. Jo, Texas, was assisting in the side-tracking of some flat cars, the hrakeman beiog at the switch-target, while he stood on the siding awaiting the approach of the cars. As they came toward him be grasped the brake to mount $\mathrm{n}$ car, when the staff broke, and be was precipitated, back downward, in front of the train, his head falling hetween two ties, while the hrake-hearn caught his hody, pushing it toward his head and turned him a complete somersault, leaving him lying on bis foce. He was found heneath the second car, three trucks having passed over him. When dragged from henenth the train his upper extremities were paralyzed and he insisted thot they were cut off, ond he would not: believe to the contrary until his gloves were remover and his hands held up for his inspection. This occurred nt five P. sr. Nothing was done for him that doy.

On July 11th, at noon, nineteen hours after the nccident, I received him at the depot at Denison, nnd had him transferred to his home, where an examination revealed a slight hruise on the right leg, another unimportant wound on the left shoulder, nnd a hruise the shope of the letter " $J$," heginning on the edge of the forehead over the right eye, running backward and nround the upper edge of the occiput, and terminating ahout where it joins the left parietal hone. This hruise was ahout an inch wide and plainly visihle, as the man was hald. 
Of the bruises and wounds be complained hut little, and said that his suffering was chiefly in his neck, particularly in the hack of the neck at the hass of ths skull, and that there was a sense of constriction in the throat. The posterior aspect of the neck presented no ahnormal condition on superficial examination, except a slight swelling ahout an inch wide at the hase of the occiput extending from one mastoid process to the other. The anterior aspect of the neck, howerer, showed a condition which I do not recollect having ever seen described. It somewhat resembled a combined case of mumps and goitre. The sterno-cleido-mastoid muscles hulged out at the angles of the jaws, and were perfectly flaccid, hut there was no swelling present. The pomum Adami was almost on a line with the chin, nnd the whole front of the neck was unduly prominent.

When this exnmination was made sensation in the upper extremities had heen partially restored; that is, complete paralysis of sensation did not exist. He only complained of n numbness und spoke of his innhility to feel a fly crawling on either hand. The ahility to move the arms and hands had also returned, hut there was no power to turn the bead hy the muscles of the neck. When agked to turn over, he replied: "Wait until I get my head," and taking it in his hands turned it with his hody.

-Realizing that this man's neck was dislocated, I directed two yssistants to taks his feet and make counter-extension, whils I took bis head, with the fingers of ons hand clutched under the eyehrows and those of the other under the occiput; violent extension was resorted to, with oscillation forward and hackward, and immediately the head assumed its proper position on top of the spinal column, all the ahnormal nppearances at once disappeared, while the patient, looking up, remarked with a laugh that the sense of constriction in the throat had left. The head, neck, and shoulders were then encased in n plaster-of-Paris mould, where they remained two weeks. At the expiration of two days the remaining numbness of the arms and hands had disappeared, except a peculiar sensation in the right fingers, which yèt remains, and which he descrihes as a feeling which would he pmduced hy washing in water containing cornmeal. On the day succeeding the reduction the temperature rose to $103^{\circ}$, hut gradunlly subsided under treatment.

In the manipulation nccessary to accomplish reduction no crepitus was noted, nor was any attempt made to discover any, ou account of the danger which might result to the spinal cord from spicula, should any be present.

On the fourth day nfter the accident there occurred a hemorrhage from the mouth, which was slight in extent. This recurred on the fifth day, and again on the sixth, when it was quite severe. It proceeded from a wound in the floor of the mouth which had heen made hy a tooth in the upper jaw. Only one tooth was present in the upper jaw-the right first molar-and it was worn down to a sharp edge on one side and 
broken off on the other. At the time of the accident so much pressure was brought to bear on the patient's head, with the jaw-bone against the hreast, that the lower jaw had been forced past the upper, until the tooth penetrated the tissues heneath the tongue.

At the end of two weeks the plaster apparatus was exchanged for one of sole leather, which was neater, lighter, and so constructed as to permit the patient to sleep upon the side.

At the end of a month he was ahle to sit up and move about the room, even going into the yard, hut in doing so used artificial support to the head. In rising from the recumbent position he has to take his head in his hands. While sitting up he leans his head against a board attacbed to the back of the chair, and while walking leans his head forward on his fist which grasps his beard. To assist his movements an apparatus was constructed of the nature of a steel backbone witb a crutch head on the upper end. This was fastened around the waist by a helt, and straps, similar to those soldiers use to carry their knapsacks, bound it to the upper part of the chest and steadied the head upon the spinal column. Continuous sitting in the erect position, however, developed a tenderness which degenerated into a pain, so that at the end of one or two hours he was compelled to lie down again. While recumbent there was no pain except upon pressure, and that limited to the apinous process of the third cervical vertebra. About the first of September, or fifty days after the accident, he began to suffer excruciating pain at the approach of a weather change. Tbis pain, though most severe in the neck, was not limited to it, hut in severe storms extended to other joints.

Ahout this time also the tissues on the back of the neck hegan to assume $n$ mottled appearance. The circulation hecame very sluggish, and most noticenbly so ahout an inch to the right of the median line, on a level with the third cervical vertehra. He spoke of a gritting or clicking with every attempt to turn the head, and an exquisite pain if the head dropped forward beyond a certain point. During the next ten days tbe circulation improved somewhat, yet it is not certain that some tissue necrosis may not yet he encountered.

At the present writing, 107 days after the accident, his condition is stationary. Tbe accompanying sketch is taken from a photograpbic side view of the patient: The bulge on the back of the neck is plainly apparent, showing that reduction did not reduce all the injured parts to their normal situation. His neck presents the appenrance of a bent knitting-needle which has been straightened, that is, it still has a kink in it.

This condition may be due either to a slight displacement of one of the cervical vertebra which was not reduced when extension was resorted to, or may have been caused by the crushing of the body of one of the 
vertehrs, ar the fracture of ono of the vertebra immediately posterior to its body. Considering all tho points presented in this interesting case, $\mathrm{my}$ belief is that therc were present both dislocatinn and fraeture.

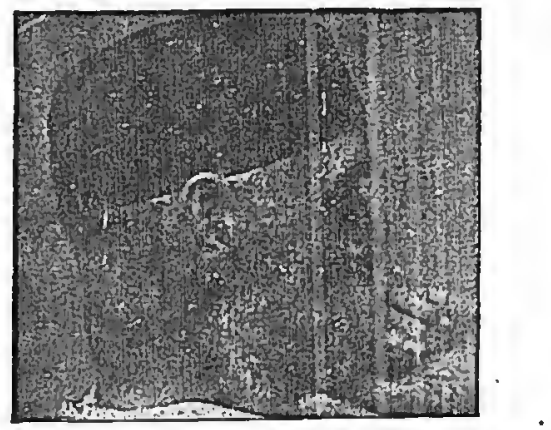

Another paint af interest is the alteratian af raiee. His voice is strong, but is sueh as is produeed by what is papularly known as "talking down in his throat." Examination af the fauces reveals nothing which will explain this, nar was there at any time any eomplaint of injury ta the lnmyx. When we consider how little of the tonsils have to be removed in order to alter the voice, it may be explnined by some nltera. tion in the size or shape of the pharyngeal cavity ton insignificant ta be deteeted.

The anly remaining evidenec af the paralysis is limited to the fingers of the right band, which be says feel as though grnvel wero eavering any artiele be tauclies.

The steel backbane referred to failing ta give him relief fram pain, a jury-mast was construeted, which he is naw wearing with same satisfaetion.

The mottled nppenrance spoken of has entirely disappeared. The suffering at the appraach of wenther cliauges yet cantinues. 